\title{
Implications of Political Stability and Financial innovations for Sectoral Economic Growth of Pakistan
}

\author{
عنوان : پِاكستان كى شعب جاتى معاشى ترقى مينسياسى استحكام اور مالياتى اخترا عات كـــ مضمرات
}

\author{
Written by: \\ Safdar Ali ${ }^{15}$ \\ https://orcid.org/0000-0003-2470-5331 \\ Khalil Ahmad ${ }^{16}$ \\ https://orcid.org/0000-0002-8277-5701
}

Muhammad Shahid ${ }^{17}$

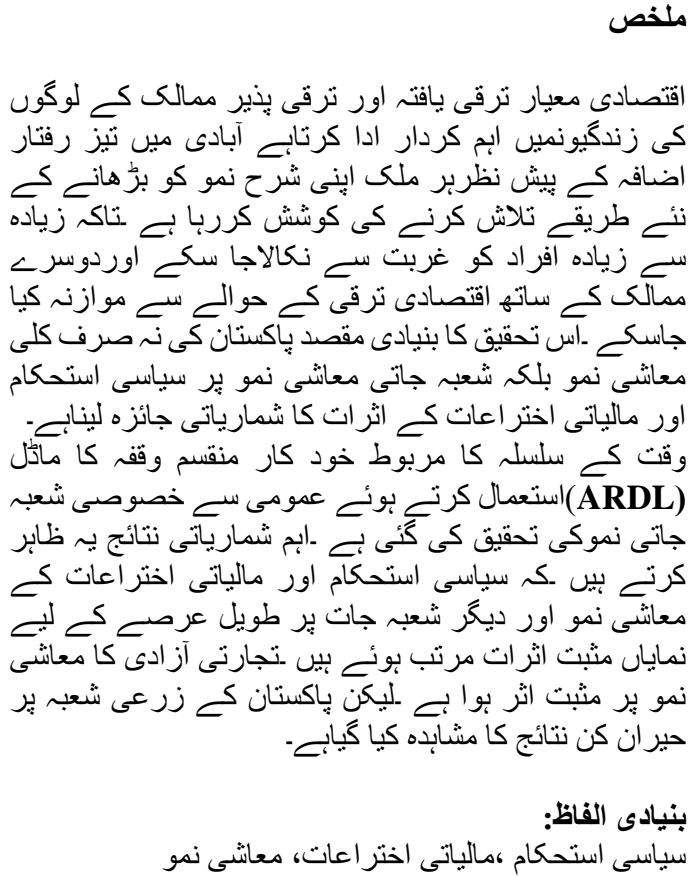

The economic status of a country plays an important role in the lives of the citizens of both developed and developing countries. With the rapid increase in population, every country is trying to find new ways to boost its growth rate so that it may elicit the maximum number of people from poverty and can compare other countries in the form of improvement. The main objective of the study is to empirically investigate the impact of political stability and financial innovations on economic growth. Furthermore, the study also analyzes the impact of subsectors (Agricultural, Industry, and Services) of the economy on growth. A time-series co-integration autoregressive distributed lag (ARDL) model is used to investigate the general to specific sector's growth. The key empirical finding shows that political stability and financial development has a positive and significant impact on economic growth as well as its sub-sectors in the long-run. Trade liberalization has a positive impact on economic growth but most surprising results have been witnessed in agriculture growth for Pakistan.

Key Word: Political Stability, Financial Development, Economic Growth.

\section{Introduction}

After World War II, most of the developed nations made policies to improve their growth and development through various socioeconomic and political strategies. They not only improved the quality of life, strengthened the political institution, and reduced the poverty level but also preserved their natural resources for future development Barro, (1991) and Easterly (1999). Neoclassical growth models considered that labor and capital formation played a very important role to determine the growth. Later on, saving, technological progress, human capital, and quality of institution were considered as key macroeconomic determinants

\footnotetext{
${ }^{15}$ Assistant professor of economics, Higher education department, Government of the Punjab, Lahore, Pakistan.

${ }^{16}$ Assistant professor of economics, Higher education department, Government of the Punjab, Lahore, Pakistan.

${ }^{17}$ Ph.D. Scholar, National College of Business Administration and Economics (NCBA\&E), Lahore, Pakistan.
} 


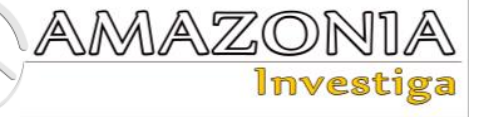

of economic growth for both developed and developing nations [Romer (1990) and Dollar and Kraay (2002)]. Haan and Siermann (1996) argue that political stability is necessary for the optimal functioning of the economy. It is not only in the socialist but also the capitalist economies; the government should guarantee to increase the wealth of nations through various economic policies and political strategies. Only political agents are not able to guarantee property rights. It will increase the uncertainty among all economic agents such as workers, businesses, and financial investors. At the later stage, some social and economic outcomes create a lack of supply and demand in all four macroeconomic markets (Gupta, 1987; Gupta and Blee, 1998).

Political stability can easily affect macroeconomic outcomes through fiscal and monetary decisions. The high Inflation rate is negatively correlated with economic growth in the long run, and it is assumed that the role of the political recession about the interest rate, monetary base, and open market operation can affect the inflation rate. Political stakeholders have also the discretionary power to determine the tax level and expenditure policy. Political stability is not the only factor that affects economic growth but economic growth has also enhanced the level of the stable political system (Rodrik, 2005; Alesina and Perotti, 1996). Alesina and Drazen (1991) also proposed why political instability may affect economic growth? Political uncertainty, with respect to the future of the institutions and policymakers, badly affects the growth rate of that country. It also influences the incentive of policymakers who either try to extend their tenure in office or try to elicit the benefits of the position. There may be another reason which can be incorporated as an important factor that affects economic growth and that is the effect of political instability on productivity.

Pakistan is high debt and aid-dependent economy with multilateral institutions playing a dominant role in both the political and economic affairs of the state, even after almost the last four decades of political unrest. Theoretically and empirically, it has been proved that political stability has a positive impact on economic growth. The GDP growth rate has been observed high and more stable during military governments in Pakistan because of macroeconomic stability in the economy. For Several times, political powers and the military ruled the institutions for socioeconomic decision making (Tabassam et al. 2016). In some ways, the growth and development that has been taken place remarkably, because it was almost inevitable, given political and economic conditions. The only issue is the degree, extent, and the form of that growth and development. Pakistan's growth and development have been a capitalist development, where the private sector has played a significant role to establish the industry. Now, Pakistan is no more an agrarian economy. The services sector contributes 52 percent in GDP, while the shares of industrial sector and agricultural sector in GDP are 25 percent and 21 percent respectively. The share composition of three sectors in GDP shows that the services sector is now a dominant sector. Although, the employment in agricultural sector has been reduced yet 40 percent of total labour force is still employed in this sectors (Zaidi, 2015).

Pakistan is a good case study because most of the time military dictators control the command of economic decision making. Furthermore, the growth rate of the economy has fluctuating behavior over the last four decades. This work not only tries to explore the impact of political stability on economic growth but it also investigates the impact on sub-sectors in the presence of core macroeconomic determinants of growth such as financial development, trade liberalization, and population growth. Pakistan is the 6th most populated country with 210 million populations and approximately 2 percent annual population growth rate. About 55 percent of its total population is living below the poverty line. In this situation when most of the population is living below the poverty line, our GDP must grow at-least with 7 percent so that we may meet the needs of the rapidly growing population. The rest of the paper explores the relevant literature in section II, model, and data describe in section III, empirical results in discussion in section IV.

\section{Literature Review}

The relationship between political system and GDP growth has gained importance among socio-political and economic researchers during last few decades in both developed and developing nations. In pervious literature, most of the empirical studies have observed the direct and indirect relationship between political stability and growth. Some studies have concluded that political stability has positive impact on growth while others have observed limited effect on growth. Hibbs (1977) among others analyzed political unrest a major cause for poor economics performance.

Mostly, in the developing economies like Pakistan, landlords and capitalists involve themselves in the politics and they often promote 
and support the policies for their interests. Additionally, Alesina and Perotti (1996) stated that political instability generates uncertainty and risk in the country which reduces the private investment leading to lower economic growth. When the volume of investment decreases, the overall production level fall at the first stage, on the later stage, it shrinks the employment size, higher prices, lower-income level, excites the inflation in the goods market as well as capital market. Various studies such as (Ozler \& Rodrick; 1992; Easterly \& Rebelo, 1993; Benhabib \& Spiegel, 1994; Barro, 1996) have also determined the negative effect of political instability on economic growth for country specific, panel, and cross section analysis. They have investigated the direct and indirect impact of political instability on growth. The earlier studies conclude that political instability negatively affects the investment, employment, productivity and inflation which ultimately affects the economic growth.

The elected governments have been tending to smooth economic progress while democratic authoritarian governments and dictatorship have interests in speedy economic development (Adelman, 1967). However, some claimed no effective relationship between authoritarian political regimes and economic growth in the long run (Weede, 1996; Goldsmith, 2004).

It has been founded in the number of studies that politically unstable governments reported slower economic growth to compare to authoritarian regimes (Alesina \& Perotti, 1994). Lastly, the instability of the political regime has been negatively related to economic performance (Jong-A-Pin, 2009; Klomp \& De Haan, 2009). The modern economy is built on an efficient financial system including financial markets, regulations, instruments, and institutions (Wachter, 2006). It proposes a payment mechanism and value addition of financial services (Nagayasu 2012; Ajide 2015). Economic growth can be accelerated by the financial system by making financial opportunities and facilities (Beck et al., 2016). Effective financial support in trade and commerce lowers the investment risk and improves economic activity (Shittu 2012; Cheng and Degryse 2014). A strong financial system stimulates growth by restructuring economic resources efficiently. The efficient resource mobilization in the economy can be traced through the development of financial markets that strengthen the capital accumulation process. Established opportunities of credit for private sector impede the financial innovations and economic growth in the economy (Levine 1997).

The studies conducted on the economy of Pakistan have tried to determine the relationship between political instability, inflation, public debt, and economic growth. Zahra et.al. (2017) explore the negative and significant impact of political instability on financial development in Pakistan. It is found an inverse relationship between political instability and public debt. Rapid economic growth in Pakistan can be achieved with political instability and a high inflation rate by reducing the level of public debt (Sallahuddin and Awan, 2017). Some West African countries have the same situation as in Pakistan. Social unrest, terrorism, unemployment, and poor governance are significant determinants hurting the growth of West African economies (Okafor, 2017). The economic growth of Pakistan has been unstable during different regimes including nationalization due to inconsistent government policies (Shahbaz et al., 2008). The low growth rate of GDP per capita is examined because of the politically unstable environment (Aisen \& Veiga, 2013; Tabassam et al. 2016).

The main factors that contribute to Pakistan's GDP growth rate are Domestic Capital, Labor force Participation Rate, Gross Domestic Education Expenditures (GDEX), Trade Openness, and Foreign Direct Investment (FDI). By keeping these factors constant, the impact of political instability provides an influence on the growth rate of the economy. Macroeconomic instability also plays a vital role in the gross domestic product growth rate. Some studies found that there is cointegration between macroeconomic instability and gross domestic product in Pakistan and macroeconomic instability has a detrimental impact on the GDP of Pakistan (Ali \& Rehman, 2015). Since hardly the study is available on Pakistan that examines the impact of political instability on sectoral growth. The present study provides an analysis of political stability and financial innovation to determine the sector-wise growth rate of the economy of Pakistan.

\section{Model and Methodology}

Economic growth defines as increasing the capacity of goods and services in the economy over a specific time. It is generally measured by the increasing rate of GDP in the economy. Economic growth is important for every nation because it increases employment, raise the consumption of goods, help to reduce the poverty 


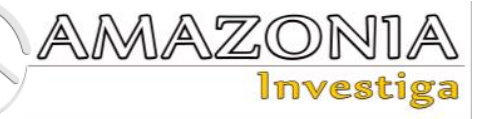

level, and overall increase the welfare of the society. The early theory believes that only saving is the main determinant of economic growth. The breakthrough in the felid, the Solow model shows that long-run growth does not only depend on labor and saving rate. Technological progress is the main cause of a persistent increase in the per capita output over a longer period. Further, the endogenous growth model augmented the technological progress depends on the learning by doing effect, investment in education, and investment in research and development for the improvements in human development. A large number of studies utilized this model and measure the level of per capita output for the country, regional, cross country, and pooled the observations. The most important among others such as empirically investigate the socio-economic determents of economic growth (Romer, 1990; Dollar and Kraay 2002; Mankiw et al, 1993; Barro 1991; King and Rebelo, 1990).

Apart from these, the endowment of natural resources and the role of the institutional factors are considered as requisites for sustainable economic growth. On one hand, Political stability considered a key determent of economic growth, on the other hand, stable economic growth plays an important role enhanced the level of stabile political system, for example, Alesina and Perotti, (1996). Alesina and Drazen (1991). Later on, Levine (1997) concluded is an ample qualification for theoretical and empirical reasoning of a first-order positive relationship between financial development and economic growth. When we talk about the relationship between trade liberalization and economic growth, a large number of studies investigate this relationship Onafowora and Oluwole (1998) and Narayan and Russell (2005). A large number of macroeconomic variables considered as sources of economic growth for developed as well as developing economies. For this study, the estimated model constructed in light of the above facts. The model can be written as following as below

$$
\mathrm{Y}=\mathrm{f}(\mathrm{K}, \mathrm{L}, \mathrm{T}, \mathrm{F}, \mathrm{P})
$$

Where,

$\mathrm{Y}=$ economic growth considered as the growth rate of GDP, $\mathrm{K}$ included as gross fixed capital formation as a share of GDP, L represents the contribution of the labor force, $\mathrm{T}$ as an export plus imports divided as GDP, $F$ is proxy of financial development as a share of GDP. P stands for political stability index. The econometrics model can be written as the following in equation 2 below.

$$
\begin{gathered}
\mathrm{Yt}=\alpha_{0}+\alpha_{1} K t+\alpha_{2} L t+\alpha_{3} \mathrm{Pt}+\alpha_{4} \mathrm{Tt}+\alpha_{5} \\
\mathrm{FDt}+\mu t
\end{gathered}
$$

Where, $\mathrm{Yt}$ is economic growth, while $\mu t$ is an error term and $t$ stand for time. The main contribution of this study is to investigate how political stability and financial development impact the sub-sectors of the economy. For agriculture sector equation 3 as follow

$$
\begin{aligned}
\mathrm{Ag} t=\beta_{0}+\beta_{1} K t & +\beta_{2} L t+\beta_{3} \mathrm{Pt}+\beta_{4} \mathrm{~T} t+\beta_{5} \mathrm{FD} t \\
& +\mathrm{e} t
\end{aligned}
$$

Where Agt stands for the growth rate of the agriculture sector with the same independent variable discuss above equations 2 and 3 . For error term, et is used for estimations. The growth of the industrial sector considered key for the total growth and development of the nation. The estimated equation of industrial sector growth in equation 4 as below

$$
\begin{gathered}
\mathrm{Igt}=\gamma_{0}+\gamma_{1} K t+\gamma_{2} L t+\gamma_{3} \mathrm{Pt}+\gamma_{4} \mathrm{~T} t+\gamma_{5} \mathrm{FDt}+ \\
\mathrm{Vt}
\end{gathered}
$$

Where Igt equal for industrial growth rate in the model $t$ is an error term and $t$ stand by time. In the last model, we investigate the larger sector of the economy, working with more than fifty percent share in total GDP. The empirical estimated equation describe as below

$$
\begin{aligned}
\mathrm{Sgt}=\lambda_{0}+\lambda_{1} K t & +\lambda_{2} L F t+\lambda_{3} \mathrm{P} t+\lambda_{4} \mathrm{~T} t+\lambda_{5} \mathrm{FD} t \\
& +\varepsilon t
\end{aligned}
$$

Time series data of GDP growth and sub-sector of Pakistan employ as dependent variables. Apart from this main variable, population growth rate, capital formation, trade liberalization, is also taken as independent variables. Data of all these variables are taken from the World Development Indicators online database and Pakistan Bureau of Statistics from 1984 to 2018. Political Stability is incorporated with an estimated absence of violence in the country and an estimated absence of terrorism in the country index calculated by World Bank for 15 years only. Estimate gives the country's score on the aggregate indicate in units of a standard normal distribution ranging from twelve different data taken from the International Country Risk Guide (ICRG) online database this is a paid data source we are not able to purchase all others subindexes. For this study, we chose only four indexes such as government quality, Rule of law, Military in politics, and bureaucrat quality. Give equal weight and using principal component analysis (PCA), and construct the normalized political stability index for Pakistan. 
The methodology of the papers based on quantities measures such as stationary of the data, co-integration of econometrics model, and later on short-run dynamics. Large numbers of models and tests for co-integration, this study choose the Autoregressive Distributed Lag Model ARDL developed by Pesaran et al, (2001) for bounds test log run relationship, and later on Narayan and Russell (2005) augmented the bounds values for decision making of hypothesis. There are few assumptions of this model, one there is no autocorrelation between variables, second time-series data must be normally distributed, third, and estimated series has no problem of unit root means data should be first difference stationary. ARDL has some advantages over previous co-integration methods such as this method is very appropriate for small data sampling or less time series observation. It is a very powerful method to investigate the short-run results without losing long-run information through the process of reparameterization.

Above specified model has been estimated for finding the coefficients of long-run and associated ECM. ARDL ( $p, q 1, q 2)$ for economic growth of different sub-sectors, political stability and financial development models because this is the generalized form of these models which have the following form:

$$
\Delta y_{t}=\alpha_{0}+\sum_{i=1}^{p} \alpha_{1} \Delta w_{t-i}+\sum_{i=1}^{q_{1}} \alpha_{2} \Delta x_{t-i}+\sum_{i=1}^{q_{2}} \alpha_{3} \Delta \text { control }_{t-i}+\varepsilon_{t}
$$

Where, y represents GDP growth along with different sub-sectors of the economy (agriculture, industry and services), $\mathrm{w}$ and $\mathrm{x}$ denote political stability and financial development respectively in different models. This specified equation is the generalized form of different models used in the study.

$$
\Delta Y_{t}=\alpha_{0}+\sum_{i=1}^{p} \alpha_{i} \Delta w_{t-i}+\sum_{j=1}^{q} \alpha_{j} \Delta x_{t-j}+\sum_{k=1}^{q} \alpha_{k} \Delta \text { CONTROL }_{t-k}+\varepsilon E T_{t-1}+\mu_{t}
$$

Where $\alpha \mathrm{i}, \alpha \mathrm{j}, \alpha \mathrm{k}$ and $\alpha \mathrm{o}$ are short-run coefficients while $\varepsilon$ is speed of adjustment of the model's convergence to equilibrium.

\section{Empirical Investigations}

To reach the optimal level of growth, it has become a hot topic for researchers that what are the factors which influence the growth rate of a country. This study is about the potential variables which affect the growth rate of Pakistan. Political stability, financial innovations
Selection of the order of ARDL ( $p, q 1, q 2)$ has been made on the basis of Schwartz Bayesian Criterion (SBC).

The short-run dynamics parameters are presented in the next step which have been obtained by estimating error correction model associated with long-run estimates. The generalized form of the model has been specified as follows:

and trade intensity, population growth, and capital formations as independent variables to check either these variables influence the GDP growth and sub-sector of the GDP of Pakistan. Table-1 shows the descriptive statistics, it shows the nature of your data before employing the regression. Our serious shows that the data set is normally distributed and there is no outlier in the data set. The measures of central tendency, normality, and data dispersion are seemed too good for regression analysis.

Table 1.

Descriptive statistics.

\begin{tabular}{llcccccccc}
\hline & GDPg & AGRg & INDg & SERg & T & L & K & P & FD \\
\hline Mean & 4.925 & 3.407 & 5.486 & 5.540 & 30.079 & 2.695 & 16.01 & 4.5 & 23.108 \\
Median & 4.588 & 3.253 & 4.903 & 5.130 & 29.966 & 2.788 & 16.45 & 4.0 & 24.039 \\
Maximum & 8.958 & 11.72 & 16.26 & 10.506 & 37.817 & 3.361 & 19.23 & 5.5 & 29.786 \\
Minimum & 0.360 & -5.208 & -5.210 & 1.330 & 24.123 & 2.055 & 11.435 & 3.0 & 15.386 \\
Std. Dev. & 1.969 & 3.346 & 3.784 & 2.231 & 3.304 & 0.436 & 1.857 & 1.6 & 3.889 \\
Skewness & 0.083 & -0.153 & 0.109 & 0.406 & 0.186 & -0.065 & -0.629 & 0.2 & -0.465 \\
\hline
\end{tabular}




\begin{tabular}{llllllllll}
\hline Kurtosis & 2.419 & 4.180 & 3.934 & 2.803 & 2.465 & 1.607 & 2.558 & 1.7 & 2.369 \\
Jarque-Bera & 0.684 & 2.791 & 1.727 & 1.308 & 0.783 & 3.669 & 3.333 & 3.3 & 2.375 \\
Probability & 0.710 & 0.247 & 0.421 & 0.5198 & 0.675 & 0.156 & 0.188 & 0.18 & 0.305 \\
Sum & 221.6 & 153.34 & 246.8 & 249.3 & 1353.5 & 121.2 & 720.6 & 150.5 & 1039.8 \\
Sum Sq. Dev. & 170.7 & 492.83 & 630.1 & 219.12 & 480.53 & 8.365 & 151.84 & 85.8 & 665.7 \\
Observations & 44 & 44 & 44 & 44 & 44 & 44 & 44 & 44 & 45 \\
\hline
\end{tabular}

The correlation matrix is very useful in quantitative and qualitative data, to measure the direction and strength of linear variables. It provides the degree of association among the variable, high association indicates the presence of multiconarality in the variables. The results reveal the trade liberalization, population growth, capital formation, political stability, and financial development has positively correlated with economic growth. Trade liberalization has negatively associated with agricultural growth but other variables have positively correlated in table-2.

Table 2.

Correlation matrix.

\begin{tabular}{llllllllll}
\hline & GDPG & AGRG & INDG & SERG & TR & POPG & INV & PS & FD \\
\hline GDPG & 1 & & & & & & & & \\
AGRG & 0.0093 & 1 & & & & & & & \\
INDG & 0.2921 & 0.1664 & 1 & & & & & & \\
SERG & 0.3332 & 0.0341 & 0.2016 & 1 & & & & & \\
TR & 0.1709 & -0.1983 & 0.2984 & 0.0727 & 1 & & & & \\
POPG & 0.4314 & 0.1764 & 0.4002 & 0.4379 & 0.0200 & 1 & & & \\
INV & 0.3137 & 0.1513 & 0.2797 & 0.0636 & 0.4911 & 0.4780 & 1 & & \\
PS & 0.2449 & 0.1085 & 0.2040 & 0.2386 & 0.0770 & -0.7440 & -0.4356 & 1 & \\
FD & 0.4405 & 0.1445 & 0.4644 & 0.2852 & 0.2691 & 0.6043 & 0.5117 & -0.614 & 1 \\
\hline
\end{tabular}

Data of 43 years from 1975 to 2018 is used to investigate the co-integration of the data. For estimations first, it is checked that either data is stationary (mean zero and variance remain constant and covariance remains zero over time) on non-stationary. Most of the series are stationary at a level such as GDP growth and subsectors of GDP along with trade liberalization but population growth and financial development are first different stationary results are reported in table-3 below. For ARDL co-integration regression analysis data set must be stationary at the level or first difference stationary. Our data pass all quality checks such as there is no autocorrelation between variables, all series are normally distributed and finally, the bottom-line is estimated series has no problem of a unit root.

Table 3.

Stationarity Test.

\begin{tabular}{lcccc}
\hline Variables & T-statistic I $(0)$ & Lages & T-statistic I $(1)$ & Lages \\
\hline GDP growth & $-4.5637^{*}$ & 0 & $-8.9868^{*}$ & 1 \\
Agri growth & $-8.7373^{*}$ & 0 & $-7.8877^{*}$ & 2 \\
Industarl growth & $-4.9894^{*}$ & 0 & $-7.8317^{*}$ & 1 \\
Services growth & $-4.2334^{*}$ & 0 & $-8.0970^{*}$ & 1 \\
Trade Liberalization & $-2.1023^{* * *}$ & 0 & $-7.6874^{*}$ & 1 \\
Population Growth & -0.8691 & 0 & $-3.4341^{*}$ & 2 \\
Capital Formation & $-2.8327^{* *}$ & 0 & $-4.9376^{*}$ & 1 \\
Political Stability & $-2.3292^{* * *}$ & 0 & $-5.5457^{*}$ & 1 \\
Financial development & -1.3710 & 0 & $-6.0326^{*}$ & 1 \\
\hline
\end{tabular}

*,**,***, indicates the $99 \%, 95 \%, 90 \%$ level of signifiance

The two-step calculation procedure has followed to measure the ARDL co-integration approach. In the first step we calculate the bounds F-statics results in table-4. Calculated F-statics are greater than the value of the upper bound in four models, it confirms the long-run association between 
growth and independents variables. It means there are some linear combinations are exit in the variables. Now we move the next step to calculate the linear coefficient of the short and long run.

Table 4.

Co-integration Test.

\begin{tabular}{llll}
\hline & F-statistic (Lages of variables) & $\begin{array}{l}\text { Lower } \\
\text { Bound }\end{array}$ & $\begin{array}{l}\text { Upper } \\
\text { Bound }\end{array}$ \\
\hline Model -1 GDPg & $6.1640 * *[1,1,2,1,2,1]$ & 2.39 & 3.38 \\
Model-2 AGRIg & $5.5721 * *[1,1,0,1,0,1]$ & 2.74 & 3.92 \\
Model -3 INDg & $9.6944 * *[1,2,1,1,2,1]$ & 2.73 & 3.93 \\
Model-4 SERg & $6.5539 * *[1,1,2,1,2,1]$ & 2.69 & 3.83 \\
\hline
\end{tabular}

**, indicates the $95 \%$ level of signifiance, $\mathrm{I}(0)$ lower bounds valus and $\mathrm{I}(1)$ represents the upper bounds valus.

Political stability has a positive impact on GDP growth as well as sub-sectors of the GDP the empirical outcomes are reported in table-5. In the industry and agriculture, with excessive profits protected by the governmental policies, we observed a great consolidation of power of this class. Interestingly, despite emerging excessive wealth, the industrialist and agriculturalist class also emerged as the political class in terms of seeking political offices. Moreover, the small middle educated class may perform in the services sector but ultimate profit moves to the private capitalist and political stakeholders. The financial development has a positive and significant impact on GDP growth and two of its sub-sectors i-e industry and services while it hurts agricultural growth.

Table 5.

Long Run Estimates.

\begin{tabular}{lllll}
\hline Variables & GDP growth & Agri Growth & Industral Growth & Serves Growth \\
\hline Trade Liberalization & $0.1752 * *$ & $-0.2302 * *$ & 0.1876 & $0.1203^{* *}$ \\
Population Growth & $0.6483^{*}$ & $0.3190^{*}$ & $0.5230^{*}$ & $0.4216^{*}$ \\
Capital Formation & 0.0211 & 0.0709 & $-0.0231^{* *}$ & $0.0241^{* *}$ \\
Political Stability & $0.4227^{* *}$ & $0.3208^{* *}$ & $0.4923^{*}$ & $0.3219^{* *}$ \\
Financialdevelopment & $0.1692^{* *}$ & $-0.1612^{* * *}$ & $0.1823^{*}$ & $0.1398^{*}$ \\
Constant & $-0.1982^{*}$ & $-0.2331^{*}$ & $-0.2013^{*}$ & $-0.3746^{*}$ \\
\hline
\end{tabular}

$*, * *, * * *$, indicates the $99 \%, 95 \%, 90 \%$ level of signifiance

The most surprising results for agriculture, trade liberalization, and financial development hurt agricultural growth. There are several reasons for it. First, the low prices of the agricultural product at the world market due to the more elastic demand for primary products. Second, our capitalists move their investment towards industries and financial services for more profitseeking. Third, the production of agriculture has fluctuating behavior due to some natural hazards such as prolonged monsoons and floods which are observed during the last four decades in Pakistan. Another aspect of this phenomenon is that credit opportunities in agriculture sector play an important role to enhance productivity and output, however, rural households may not be able to access the credit because of the lack of gaurantees, especially the institutional sources hardly provide the credit facilities to rural households. So, the non-institutional or informal sources of credit dominate the rural sector. On the other hand, rural elites and politicians have better opportunities to institutional credit. Thus, the poor farmer is exploited through the noninstitutional credit sources which is highly expensive, however, the elites enjoy the benefits of cheaper institutional crredit.

Capital formation has a positive impact on economic growth and sub-sectors of GDP except for industrial sector growth. This result has also several reasons for it. First, The capital-output ratio is so high due to unfavorable policies by the political institutions. Second, the high-interest rate set by the government. Third, the high cost of production due to energy crises, political 


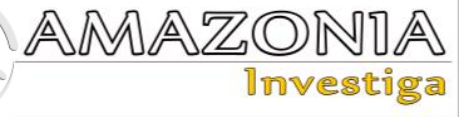

unrest, and terrorist attack harms the capital formation growth in the industrial sector. Trade liberalization has a positive but insignificant impact on industrial growth. The share of industrial exports has no significant contribution

Table 5.

Short-run dynamics.

\begin{tabular}{lllll}
\hline Variables & $\Delta$ GDP growth & $\Delta$ Agri Growth & $\begin{array}{l}\Delta \text { Industral } \\
\text { Growth }\end{array}$ & $\Delta$ Serves Growth \\
\hline$\Delta$ rade Liberalization & $-0.0227^{* *}$ & $-0.4032^{* *}$ & 0.1833 & $-0.0912^{*}$ \\
$\Delta$ Population Growth & $-0.1396^{*}$ & $0.3454^{*}$ & $0.2360^{*}$ & $0.3221^{*}$ \\
$\Delta$ Capital Formation & $0.3114^{*}$ & $0.4362^{*}$ & $-0.1531^{* *}$ & $0.4413^{* *}$ \\
$\Delta$ Political Stability & $0.2273^{*}$ & $-0.2643 * *$ & $0.4092^{*}$ & $0.1382^{*}$ \\
$\Delta$ Financial development & $0.2767 * * *$ & -0.2867 & $0.1823^{*}$ & $0.2899^{* * *}$ \\
ECM $_{\mathrm{t}-1}$ & $-0.6760^{*}$ & $-0.7321^{*}$ & $-0.3913 *$ & $-0.1720^{*}$ \\
$\mathrm{R}^{2} / \mathrm{DW}$ & $0.9273 / 2.012$ & $0.9025 / 2.133$ & $0.8703 / 2.220$ & $9189 / 2.235$ \\
\hline
\end{tabular}

*,**,***, indicates the $99 \%, 95 \%, 90 \%$ level of signifiance

The table represents the short-run coefficient estimates obtained from the ECM version of the ARDL model. The ECM coefficient shows the speed of adjustment to restore the equilibrium in the model. It should have a statistically significant coefficient with a negative sign. The results show that political stability and financial development have a positive and significant impact on GDP growth, industrial growth, and services growth in the short run. However, these hurt agricultural growth. As it has been discussed in the long run results, the poor who reside in the towards trade openness due to lack of economies of scale and scope in major exporting textile industry decline trends last fifteen years in Pakistan.

Table 6.

Summary Statistics of Diagnostic Tests.

\begin{tabular}{llll}
\hline Breusch-Godfre Test & LM Version & \multicolumn{1}{c}{ F Version } & Conclusion \\
\hline Model-1 GDPg & $0.3558[0.65]$ & $0.4201[0.69]$ & \\
Model-2 AGRg & $0.2458[0.32]$ & $0.3139[0.43]$ & No Serial Correlation \\
Model-3 INDg & $0.4236[0.87]$ & $0.5325[0.56]$ & \\
Model-4 SERg & LM Version & F Version & \\
Ramsey's RESET Test & $0.6742[0.76]$ & $0.7858[0.86]$ & Models are Stable \\
GDPg & $0.3377[0.65]$ & $0.24078[0.67]$ & \\
AGRg & $0.0048[0.55]$ & $0.0032[0.65]$ & \\
INDg & LM Version & F Version & \\
SERg & $0.6712[0.21]$ & $2.134[0.45]$ & No Heteroskedasticity \\
Heteroskedasticity Test & $0.4560[0.19]$ & $1.9674[0.20]$ & \\
GDPg & $0.3562[0.21]$ & $1.9622[0.22]$ & \\
AGRg & CUSUM & CUSUM SQUARS & \\
INDg & Stable & Stable & Residual are stable \\
SERg & Stable & Stable & \\
Recursive Residual & Unstable & Stable & \\
GDPg & AGRg & & \\
INDg & &
\end{tabular}

Table- 6 shows that the summary statics of all relevant diagnostic tests od the above four models. The above-calculated F-statics and LM rural areas of Pakistan and are especially involved in agriculture or agricultural activities, they do not have access to credit. The poor farmers do not have sufficient amounts to use the agricultural inputs which may enhance the production and productivity of the agricultural sector. Moreover, they are exploited by rural elites and do not have opportunities to raise their agricultural output. However, the political and economic elites invest their capital in the industrial and services sectors which results in the enhanced growth of these sectors. version of test statistics shows the absence of serial correlation and heteroscedasticity in all four empirical analysis. The no existence of 
autocorrelation in recursive residual. Furthermore, the reset test also confirms the good fit and empirical analysis for short and long-run coefficient reliability.

\section{Conclusions and policy suggestions}

In this study, we try to investigate the impact of political stability and financial innovation on economic growth for country-specific Pakistan. This case study also analysis the sub-sectors of GDP growth such as the growth of agriculture, industrial, and services. For this, we use timeseries data and autoregressive distrubatited lag models for both long and short-run cointegration. Growth has so many economic, social, and political departments. For macroeconomic determents, labor and capital formation, trade and financial development for an open economy, and political stability index are used to capture the role of political institutions. When we review the literature, political stability has a positive and robust impact on economic growth for developed and developing nations along with macroeconomic variables. The main contribution of the study to investigate the impact of political stability on sub-sectors' growth of GDP in Pakistan.

The results show that political stability has a positive impact on GDP and sub-sector growth in Pakistan because political stability enhances the quality of governance and also improves the quality of the rule of law. Capital formation has a positive impact on economic growth and subsectors of GDP except for industrial sector growth. This result shows capital out-put ratio is so high due to unfavorable policies by the political institutions. Financial development has a positive impact on industrial and services sectors but the most surprising results against agricultural growth in Pakistan. This result shows the agriculture sector has less profitable for the investor due to many reasons. One, financial development move faster with the help of digitalization of agri markets, Second, a large informal sector already work for agriculture loan and financial market. Third, the investors are likely to invest in stable sectors but unfortunately, our production has so many fluctuations due to natural hazards in Pakistan. Trade liberalization has also a negative impact on agricultural growth due to a lack of comparative advantages in this sector. The prices of agriculture products are more elastic as compared to manufacture items worldwide.

This study empirically advocates the notion that financial developments along with political stability are the significant factors that lead economic growth. For policy suggestions, we should improve our political stability and enhance the financial and capital formation agricultural sector and the industrial sector with government stable policies in the future. Especially we should establish a sound financial system with innovations and a more powerful and sustainable political system that can boost the activities for sustainable economic growth.

Its future growth of the agriculture sector will also attain the economies of scale and scope in industrial sector growth. This policy may create comparative advantages for international trade in the future.

\section{References}

Adelman, I. \& Morris, C.T. (1967). Society, politics, and economic development. Baltimore: John Hopkins University Press.

Aisen, A., \& Veiga, F. J. (2013). How does political instability affect economic growth?. European Journal of Political Economy, 29(1), 151-167.

Ajide, F.M. (2015). Financial Innovation and Sustainable Development in Selected Countries in West Africa. Innovation Finance, 15(2), 85112.

Alesina, A., \& Drazen, A. (1991). Why are stabilization delayed. American Economic Review, 1170-1188.

Alesina, A., \& Perotti R. (1996). Income distribution, political instability and Investment. European Economic Review, 40(6), 1203-1228.

Alesina, A., \& Perotti, R. (1994). The political economy of growth: a critical survey of the recent literature. The World Bank Economic Review, 8(3), 351-371.

Ali, A., \& Rehman, H. U. (2015). Macroeconomic instability and its impact on gross domestic product: an empirical analysis of Pakistan. Pakistan Economic and Social Review, 53(2), 285-316.

Barro, R. (1991) Economic Growth in a Cross Section of Countries. Quarterly Journal of Economics, 106, 407-442.

Barro, R. J. (1996). Institutions and growth, an introductory essay. Journal of Economic Growth, 1(2), 145-148.

Beck, T., Chen, T., Lin, C., \& Song, F. M. (2016). Financial innovation: The bright and the dark sides. Journal of Banking \& Finance, 72, 28-51.

Benhabib, J., \& Spiegel, M. M. (1994). The role of human capital in economic development evidence from aggregate cross-country data. Journal of Monetary economics, 34(2), 143-173. 


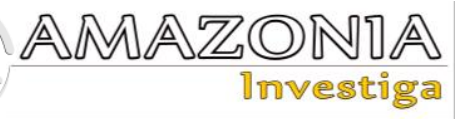

Cheng, X., Degryse, H (2014). The Impact of Bank and Non-Bank Financial Institutions on Local Economic Growth in China. Journal of Financial Services Research, 37(2), 179-199.

Dollar, D \& Kraay, A. (2002) Growth Is Good for the Poor. Journal of Economic Growth, 7, 195-225.

Easterly, W. (1999). The Ghost of Financing Gap: Testing the Growth Model Used in the International Finance Institutions. Journal of Development Economics, 60(2), 423-438.

Easterly, W., \& Rebelo, S. (1993). Fiscal policy and economic growth. Journal of Monetary Economics, 32(3), 417-458.

Goldsmith, A, A. (2004) Predatory versus developmental rule in Africa. Democratization, 11(3), 88-110

Gupta, D. K. (1987). Political psychology and neoclassical theory of economic growth: The possibilities and implications of an attempted resynthesize. Political Psychology, 8(4) 637665.

Gupta, D., \& Blee, A. (1998). Democracy, economic growth and political instability: An integrated perspective. Journal of SocioEconomics, 27, 587-611.

Haan, D. J \& Siermann, C, J. (1996). Political Instability, Freedom, and Economic Growth: Some Further Evidence. Economic Development and Cultural Change, 44 (2), 339-350.

Hibbs, D. A. (1977). Political parties and macroeconomic policy. American Political Science Review, 71(04), 1467-1487.

Jong-A-Pin, R. (2009). On the measurement of political instability and its impact on economic growth. European Journal of Political Economy, 25(1), 15-29.

King, R. \& Rebelo, S. (1990). Public Policy and Economic Growth: Developing Neoclassical Implications. Journal of Political Economy, 98 (1), 126-151.

Klomp, J., \& de Haan, J. (2009). Political institutions and economic volatility. European Journal of Political Economy, 25(3), 311-326.

Levine, R. (1997). Financial Development and Economic Growth: Views and Agenda. Journal of Economic Literature, 35(1), 688-726.

Mankiw, N. G., David, R., \& David, N. W., (1992). A Contribution to the Empirics of Economic Growth. The Quarterly Journal of Economics, 107(2), 407-437.

Memon, A, P., Memon, K, S, Shaikh, S., \& Memon, F. (2010). Political Instability: A case study of Pakistan. Journal of Political Studies, 18(1), 31-43.

Nagayasu, J. (2012). Financial innovation and regional money. Applied Economics, 44(35), 4617-4629.
Narayan, P., \& Russell, S., (2005). Trade liberalization and economic growth in Fiji. An Empirical Assessment Using the ARDL Approach. Journal of the Asia pacific Economy, 10(1), 96-115.

Okafor, G. (2017). The impact of political instability on the economic growth of ECOWAS member countries. Defence and Peace Economics, 28(2), 208-229.

Onafowora, O. A., \& Oluwole, O., (1998). Can Trade Liberalization Stimulate Economic Growth in Africa? World Development, 26(3), 479-506.

Pesaran, M.H., Shin, Y., \& Smith, R.J. (2001). Bound Testing Approaches to theAnalysis of Level Relationship. Journal of Applied Economics, (16), 289-326.

Rodrik, D. (2005). Why We Learn Nothing from Regressing Economic Growth on Policies. Cambridge: Harvard University.

Romer, P.M. (1990). Endogenous Technological Change. Journal of Political Economy, 98(5), 71-102.

Sallahuddin, N. A., \& Awan, A. G. (2017). Impact of Political Instability on Pakistan's Economic Growth. Global Journal of Management, Social Sciences and Humanities, 3(4), 729-748.

Shahbaz, M., Khalil, A., \& A. R. Chaudhary, (2008). Economic Growth and Its Determinants in Pakistan. The Pakistan Development Review, 47(4), 471-486.

Shittu, A. I. (2012). Financial intermediation and economic growth in Nigeria. British Journal of Arts and Social Sciences, 4(2), 164-179.

Tabassam, A. H., Hashmi, S. H., \& Rehman, F. U. (2016). Nexus between political instability and economic growth in Pakistan. ProcediaSocial and Behavioral Sciences, 230, 325-334.

Wachter, J.A. (2006) Comment on: Can financial innovation help to explain the reduced volatility of economic activity? Journal of Monetary Economics, 53, 151-154.

Weede, E. (1996). Political regime type and variation in economic growth rates. Constitutional political economy, 7(3), 167-176. Zahra, T., Waheed, A., Mahmood, H., \& Rafique. M. A. (2017). Impact of political instability on financial development of Pakistan. International Journal of Management Sciences and Business Research, 6(4), 1-13.

Ozler, S., \& Rodrik, D. (1992). External Shocks, Politics and Private Investment: Some Theory and Empirical Evidence. Journal of Development Economics, 39(1), 141-162.

Zaidi, S. A. (2015). Issues in Pakistan's Economy: A political Economy Perspective. Oxford University Press. 